\title{
PENGARUH PENERAPAN METODE KOOPERATIF TIPE INVESTIGASI KELOMPOK TERHADAP KEMAMPUAN KOMUNIKASI MATEMATIS DAN SELF CONFIDENCE SISWA SMP
}

\author{
Erfan Sufena $^{1}$ Suyono $^{2}$ Lukman El Hakim $^{3}$
}

\begin{abstract}
This study aims to see the influence of cooperative methods of group investigation type (hereinafter abbreviated as MKTIK) to the ability of mathematical communication and self confidence of students. This research was conducted at SMP Negeri 123 Jakarta in the academic year 2016/2017. The research method used quasi experiment (quasi experiment). The reasonably affordable population of this study is four classes in SMP Negeri 123 Jakarta (two classes studying through cooperative type-type investigative methods and two classes that received conventional learning). After testing, the data used are normally distributed, have the same or homogeneous variance, and have an average similarity. The result of this research are 1) there are difference of mathematical communication ability of students who learn through MKTIK compared with students who get conventional learning, 2) there is interaction influence between learning method and mathematical early ability to students mathematical communication ability, 3) there is difference of students' mathematical communication ability With a high mathematical early ability to learn through MKTIK compared with students who received conventional learning, 4) there was no difference in mathematical communication ability of students with low early mathematical skills learning through MKTIK compared with students who received conventional learning, and 5) there was a difference of self confidence Students who learn through MKTIK compared with students who received conventional learning.
\end{abstract}

Keywords: Mathematical Communication Ability, Self Confidence, Cooperative Type Method of Group Investigation.

ABSTRAK: Penelitian ini bertujuan untuk melihat pengaruh metode kooperatif tipe investigasi kelompok (untuk selanjutnya disingkat menjadi MKTIK) terhadap kemampuan komunikasi matematis dan self confidence siswa. Penelitian ini dilaksanakan di SMP Negeri 123 Jakarta pada tahun pelajaran 2016/2017. Metode penelitian yang digunakan quasi eksperiment (eksperimen semu). Populasi terjangkau penelitian ini adalah empat kelas di SMP Negeri 123 Jakarta (dua kelas yang belajar melalui metode kooperatif tipe investigasi kelompok dan dua kelas yang mendapat pembelajaran konvensional). Setelah dlakukan pengujian, data yang digunakan berdistribusi normal, memiliki varians yang sama atau bersifat homogen, dan memiliki kesamaan rata-rata. Hasil penelitian ini adalah 1) terdapat perbedaan kemampuan komunikasi matematis siswa yang belajar melalui MKTIK dibandingkan dengan siswa yang mendapat pembelajaran konvensional, 2) terdapat pengaruh interaksi antara metode pembelajaran dan kemampuan awal matematis terhadap kemampuan komunikasi matematis siswa, 3) terdapat perbedaan kemampuan komunikasi matematis siswa dengan kemampuan awal matematis tinggi yang belajar melalui MKTIK dibandingkan dengan siswa yang mendapat pembelajaran konvensional, 4) tidak terdapat perbedaan kemampuan komunikasi matematis siswa dengan kemampuan awal matematis rendah yang belajar melalui MKTIK dibandingkan dengan siswa yang mendapat

\footnotetext{
${ }^{1}$ Mahasiswa Magister Pendidikan Matematika, Universitas Negeri Jakarta, Email: erfan.sufena@yahoo.com

${ }^{2}$ Dosen Magister Pendidikan Matematika, Universitas Negeri Jakarta

${ }^{3}$ Dosen Magister Pendidikan Matematika, Universitas Negeri Jakarta
} 


\title{
Pengaruh Penerapan Metode Kooperatif Tipe Investigasi Kelompok Terhadap Kemampuan Komunikasi Matematis dan Self Confidence Siswa SMP
}

\author{
ERFAN SUFENA, SUYONO, LUKMAN EL HAKIM
}

pembelajaran konvensional, dan 5) terdapat perbedaan self confidence siswa yang belajar melalui MKTIK dibandingkan dengan siswa yang mendapat pembelajaran konvensional.

Kata Kunci: Kemampuan Komunikasi Matematis, Self Confidence, Metode Kooperatif Tipe Investigasi Kelompok.

\section{PENDAHULUAN}

Tujuan pembelajaran matematika yang dirumuskan oleh National Council of Teacher of Mathematics (2000), yaitu: (1) belajar untuk pemecahan masalah (2) belajar untuk penalaran dan pembuktian, (3) belajar untuk kemampuan mengaitkan ide matematis, (4) belajar untuk komunikasi matematis, (5) belajar untuk representasi matematis. Berdasarkan tujuan pembelajaran matematika di atas, terlihat bahwa salah satu aspek yang ditekankan dalam kurikulum KTSP dan NCTM adalah meningkatkan kemampuan komunikasi matematis siswa. Komunikasi matematis merupakan hal yang sangat penting dan harus dimiliki oleh siswa. Sesuai dengan yang terdapat dalam The National Council of Teachers of Mathematics (2000) dijelaskan bahwa komunikasi adalah suatu bagian esensial dari matematika dan pendidikan matematika. Pendapat ini mengisyaratkan pentingnya komunikasi dalam pembelajaran matematika. Melalui komunikasi, siswa dapat menyampaikan ide-ide yang dimiliki kepada guru dan siswa yang lain. Namun pada kenyataannya masih banyak ditemukan siswa yang memiliki kemampuan komunikasi matematis rendah. Hal ini terlihat dari hasil penelitian Rohaeti (2003) dan Wihatma (2004) yang menyatakan bahwa rata-rata kemampuan komunikasi matematis siswa SLTP berada pada kualifikasi kurang dan dalam mengomunikasikan ide-ide matematika termasuk dalam kualifikasi kurang sekali.

Kegiatan pembelajaran juga sarat dengan muatan psikologis. Salah satu aspek psikologi yang terpengaruh terhadap pembelajaran adalah aspek kepercayaan diri (self confidence). Self confidence dapat diartikan sebagai sejauh mana seseorang memiliki keyakinan terhadap penilaian atas kemampuan yang dimiliki dan sejauh mana dapat merasakan adanya "kepantasan" untuk berhasil. Neill (2005) menjelaskan bahwa self confidence itu sendiri merupakan kombinasi dari self esteem dan self efficacy. Menurut Lie (2003), seseorang yang percaya diri dapat menyelesaikan tugas atau pekerjaan yang sesuai dengan tahapan perkembangan dengan baik, merasa berharga, memiliki keberanian, dan kemampuan untuk meningkatkan prestasi, mempertimbangkan berbagai pilihan, serta membuat keputusan sendiri merupakan perilaku yang mencerminkan percaya diri. Siswa yang memiliki kepercayaan diri dapat menyelesaikan tugas atau pekerjaan yang sesuai dengan kemampuan yang dimiliki, maka hal ini akan berdampak positif terhadap siswa, sehingga siswa menjadi lebih yakin dan dapat meningkatkan prestasi yang diperoleh. Namun pada kenyataannya masih banyak ditemukan siswa yang merasa kurang percaya diri dan selalu berusaha mengetahui hasil kerja teman lain pada saat menerima tugas dari guru. Hal ini didukung oleh fakta yang ditunjukkan oleh Rohayati (2011), yaitu masih banyak siswa Indonesia kurang memiliki rasa percaya diri. Siswa akan merasa gugup dan tegang jika dihadapkan pada suatu masalah.

Salah satu faktor yang menyebabkan kemampuan komunikasi matematis dan self confidence siswa rendah adalah model pembelajaran yang diterapkan oleh guru masih belum tepat sasaran dan bermakna. Belum tepat sasaran artinya pembelajaran yang dilakukan masih bersifat konvensional, tidak sesuai dengan 


\section{Pengaruh Penerapan Metode Kooperatif Tipe Investigasi Kelompok Terhadap Kemampuan Komunikasi Matematis dan Self Confidence Siswa SMP}

\section{ERFAN SUFENA, SUYONO, LUKMAN EL HAKIM}

karakteristik siswa dan materi matematika yang bersifat abstrak. Dalam pembelajaran konvensional, guru senantiasa menjadi pusat perhatian karena harus mendemonstrasikan matematika yang sudah siap saji dan dipandang sebagai ilmu yang sangat ketat.

Berdasarkan uraian di atas perlu dilakukan suatu inovasi pembelajaran untuk meningkatkan kemampuan komunikasi matematis dengan memperhatikan self confidence siswa. Salah satunya adalah dengan menerapkan model pembelajaran yang berbeda dari pembelajaran konvensional.

Menurut Winayawati, dkk (2012), model pembelajaran kooperatif adalah suatu model pembelajaran yang mengutamakan kerjasama antarsiswa untuk mencapai tujuan pembelajaran. Dengan model ini diharapkan siswa melalui kegiatan berdiskusi akan lebih aktif untuk bertanya minimal kepada teman sendiri kemudian siswa diminta untuk mempresentasikan hasil pekerjaan kelompok di depan kelas untuk melatih self confidence mereka menyampaikan pendapat sedangkan kelompok lain menanggapi.

Model pembelajaran kooperatif memiliki banyak variasi metode, salah satunya adalah metode kooperatif tipe investigasi kelompok (untuk selanjutnya disingkat menjadi MKTIK). MKTIK adalah metode yang menekankan pada partisipasi dan aktivitas siswa untuk menginvestigasi sendiri materi pelajaran yang akan dipelajari melalui bahan-bahan yang tersedia misalnya buku paket, atau siswa dapat mencari melalui internet. Metode ini melatih siswa untuk memiliki kemampuan yang baik dalam berkomunikasi maupun dalam keterampilan proses kelompok, sehingga akan menumbuhkan kemampuan komunikasi matematis siswa. Metode ini juga dapat melatih siswa menumbuhkan kemampuan berpikir mandiri. Keterlibatan siswa secara aktif dapat dilihat mulai dari tahap pertama hingga akhir pembelajaran.

Penerapan MKTIK yang sesuai dengan langkah-langkah yang di harapkan dalam pembelajaran maka akan dapat meningkatkan self confidence siswa dan hasil belajar siswa. Dalam penerapan MKTIK, siswa harus mempunyai self confidence yang tinggi untuk dapat mengomunikasikan atau menjelaskan ide-ide yang dimiliki, baik secara tertulis maupun tidak tertulis. Hal ini dapat dilihat pada kegiatan siswa saat diskusi kelompok dan presentasi. Saat diskusi kelompok siswa harus memliki pengendalian diri yang baik, tidak mudah marah ketika pendapat siswa tersebut dikritik oleh orang lain. Saat presentasi di depan kelas, siswa harus yakin akan kemampuan diri sendiri. Dalam mengomunikasikan ide yang dimiliki, siswa juga harus memiliki kemampuan berkomunikasi yang baik, hal ini bertujuan agar pesan yang akan disampaikan dapat diterima dengan baik oleh pendengar.

Banyak yang sudah meneliti kemampuan komunikasi matematis dan self confidence siswa, diantaranya hasil penelitian Solekha, dkk (2013) yang menunjukkan bahwa MKTIK berpengaruh terhadap kemampuan komunikasi matematis siswa. Kemudian hasil penelitian Edison (2015) yang menunjukkan bahwa jika ditinjau berdasarkan faktor pembelajaran maka terdapat perbedaan peningkatan kemampuan pemahaman matematis dan self confidence antara siswa yang belajar dengan MKTIK dibandingkan dengan siswa yang belajar dengan pembelajaran langsung. Dan hasil penelitian Khoerunnisa, dkk (2016) yang menunjukkan bahwa rata-rata kemampuan komunikasi matematis siswa kelas-VII menggunakan pembelajaran TTW berbantuan alat peraga mandiri lebih baik dari rata-rata kemampuan komunikasi matematis siswa menggunakan pembelajaran 


\section{Pengaruh Penerapan Metode Kooperatif Tipe Investigasi Kelompok Terhadap Kemampuan Komunikasi Matematis dan Self Confidence Siswa SMP}

\section{ERFAN SUFENA, SUYONO, LUKMAN EL HAKIM}

konvensional dan skor percaya diri siswa kelas-VII menggunakan pembelajaran TTW berbantuan alat peraga mandiri lebih tinggi dari skor percaya diri siswa menggunakan pembelajaran konvensional.

\section{METODE PENELITIAN}

Penelitian ini dilaksanakan di SMP (Sekolah Menengah Pertama) Negeri 123 Jakarta. Metode yang digunakan dalam penelitian ini adalah metode quasi eksperimen. Data yang digunakan dalam penelitian ini adalah data yang diambil berdasarkan hasil tes kemampuan komunikasi matematis dan angket self confidence diakhir pembelajaran. Sebelum memulai pembelajaran siswa diberikan tes kemampuan awal matematis untuk menentukan kelompok siswa yang memiliki kemampuan awal matematis tinggi dan rendah.

Populasi yang dimaksud dalam penelitian ini adalah seluruh siswa kelas VIII SMP Negeri 123 Jakarta pada semester genap pada tahun pelajaran 2016/2017. Teknik pengambilan sampel dengan multistage random sampling. Hasil pemilihan sampel secara acak menetapkan kelas VIII C dan D dengan jumlah siswa sebanyak 65 orang sebagai kelompok eksperimen yang belajar melalui metode kooperatif tipe investigasi kelompok (untuk selanjutnya disingkat menjadi MKTIK) dan Kelas VIII B dan E dengan jumlah siswa sebanyak 65 orang sebagai kelompok kontrol yang mendapat pembelajaran konvensional.

\section{HASIL DAN PEMBAHASAN}

Tabel 1.

Hasil Uji ANOVA Dua Jalan Pengaruh dan Interaksi Metode Pembelajaran dan Kemampuan Awal Matematis terhadap Kemampuan Komunikasi Matematis Siswa

Tests of Between-Subjects Effects

Dependent Variable: Kemampuan Komunikasi Matematis

\begin{tabular}{|l|r|r|r|r|r|}
\hline Source & $\begin{array}{c}\text { Type III Sum of } \\
\text { Squares }\end{array}$ & df & Mean Square & \multicolumn{1}{|c|}{ F } & Sig. \\
\hline Corrected Model & $364,045^{\mathrm{a}}$ & 3 & 121,348 & 20,309 &, 000 \\
Intercept & 9660,045 & 1 & 9660,045 & 1616,715 &, 000 \\
Metode & 210,182 & 1 & 210,182 & 35,176 &, 000 \\
KAM & 26,182 & 1 & 26,182 & 4,382 &, 039 \\
Metode * KAM & 127,682 & 1 & 127,682 & 21,369 &, 000 \\
Error & 501,909 & 84 & 5,975 & & \\
Total & 10526,000 & 88 & & & \\
Corrected Total & 865,955 & 87 & & & \\
\hline
\end{tabular}

a. R Squared $=, 420$ (Adjusted R Squared $=, 400$ )

Berdasarkan Tabel tersebut, terlihat bahwa semua nilai pada kolom Sig. < 0,05 , sehingga dapat dikatakan bahwa terdapat perbedaan yang signifikan pada kemampuan komunikasi matematis siswa yang belajar melalui MKTIK dan pembelajaran konvensional jika dikelompokkan berdasarkan kemampuan awal matematis, serta terdapat interaksi antara metode pembelajaran dan kemampuan 
Pengaruh Penerapan Metode Kooperatif Tipe Investigasi Kelompok Terhadap
Kemampuan Komunikasi Matematis dan Self Confidence Siswa SMP

\section{ERFAN SUFENA, SUYONO, LUKMAN EL HAKIM}

awal matematis terhadap kemampuan komunikasi matematis. Selanjutnya akan dilakukan uji lanjut dengan menggunakan uji-t.

Tabel 2

Hasil Uji-t Perbedaan Kemampuan Komunikasi Matematis melalui MKTIK Dibandingkan dengan Siswa yang Mendapat Pembelajaran Konvensional

Independent Samples Test

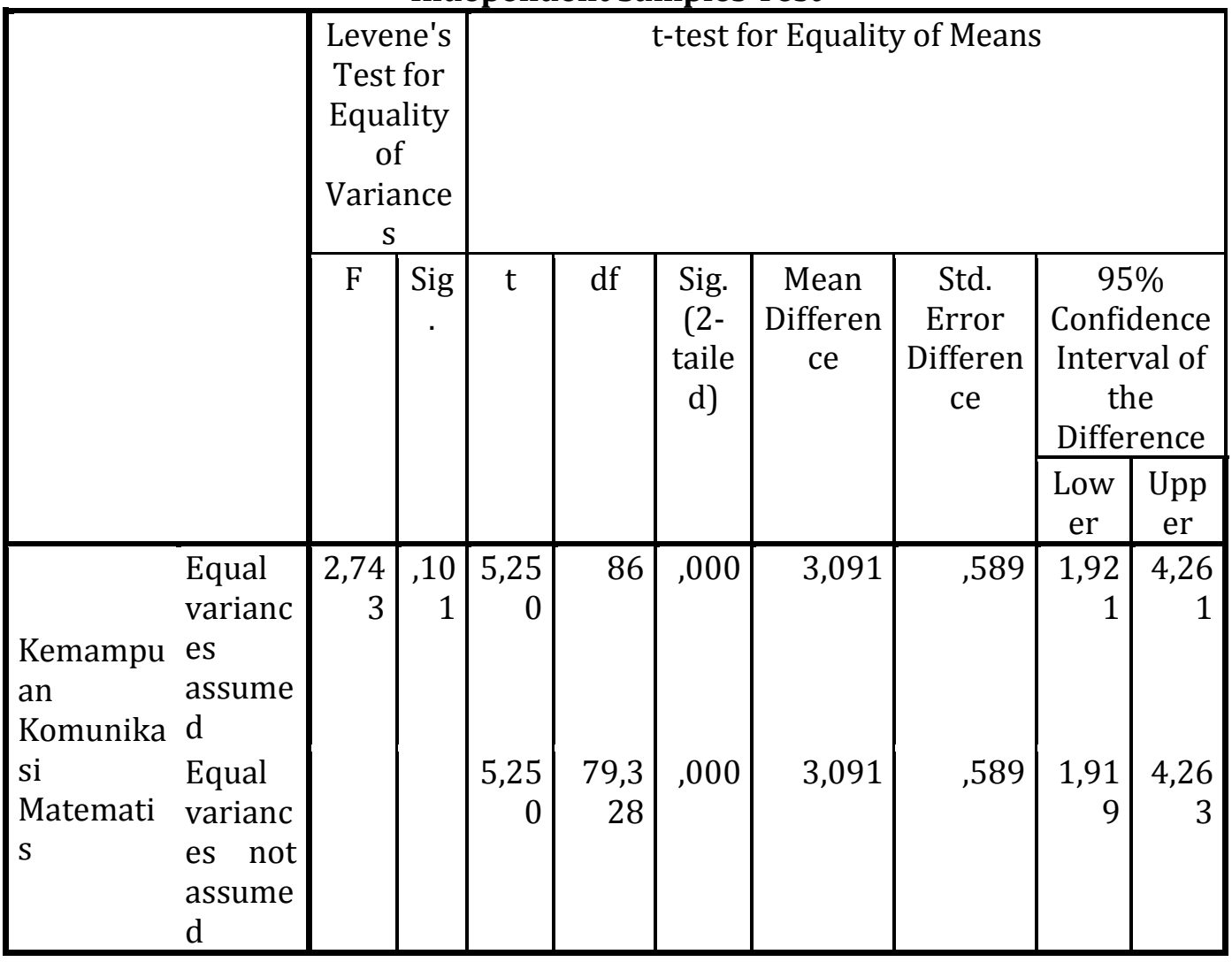

Berdasarkan Tabel tersebut, terlihat bahwa nilai $t=5,250$ dan $\mathrm{df}=86$, pada taraf signifikansi $=0,05$ dengan menggunakan Microsoft Excel diperoleh nilai $t_{\text {tabel }}=$ 1,988, sehingga dapat dikatakan bahwa nilai $t>$ nilai $t_{\text {tabel, }}$ yang berarti bahwa hipotesis penelitian $\mathrm{H}_{0}$ ditolak. Jadi, dapat disimpulkan bahwa terdapat perbedaan kemampuan komunikasi matematis siswa yang belajar melalui MKTIK dan pembelajaran konvensional dan dapat disimpulkan juga bahwa kemampuan komunikasi matematis siswa yang belajar melalui MKTIK lebih tinggi dibandingkan dengan siswa yang mendapat pembelajaran konvensional.

Pengaruh Interaksi antara Metode Pembelajaran dan Kemampuan Awal Matematis terhadap Kemampuan Komunikasi Matematis Siswa

Berdasarkan Tabel 1, terlihat bahwa faktor interaksi antara metode pembelajaran dan kemampuan awal matematis menimbulkan pengaruh interaksi, pada kolom Metode * KAM terlihat bahwa nilai Sig. $<0,05$, sehingga dapat dikatakan 


\section{Pengaruh Penerapan Metode Kooperatif Tipe Investigasi Kelompok Terhadap Kemampuan Komunikasi Matematis dan Self Confidence Siswa SMP}

\section{ERFAN SUFENA, SUYONO, LUKMAN EL HAKIM}

bahwa terdapat interaksi yang signifikan antara faktor metode pembelajaran dan kemampuan awal matematis terhadap kemampuan komunikasi matematis.

Dapat disimpulkan bahwa interaksi terjadi jika metode pembelajaran dan kemampuan awal matematis secara bersama-sama memberikan pengaruh yang signifikan terhadap kemampuan komunikasi matematis, sehingga dapat dikatakan bahwa kemampuan komunikasi matematis dipengaruhi oleh kemampuan awal matematis yang dimiliki oleh siswa dan metode pembelajaran yang diterapkan oleh guru. Penerapan metode pembelajaran didukung oleh kemampuan awal matematis. Untuk lebih jelas, berikut disajikan gambar grafik interaksi antara metode pembelajaran dan kemampuan awal matematis.

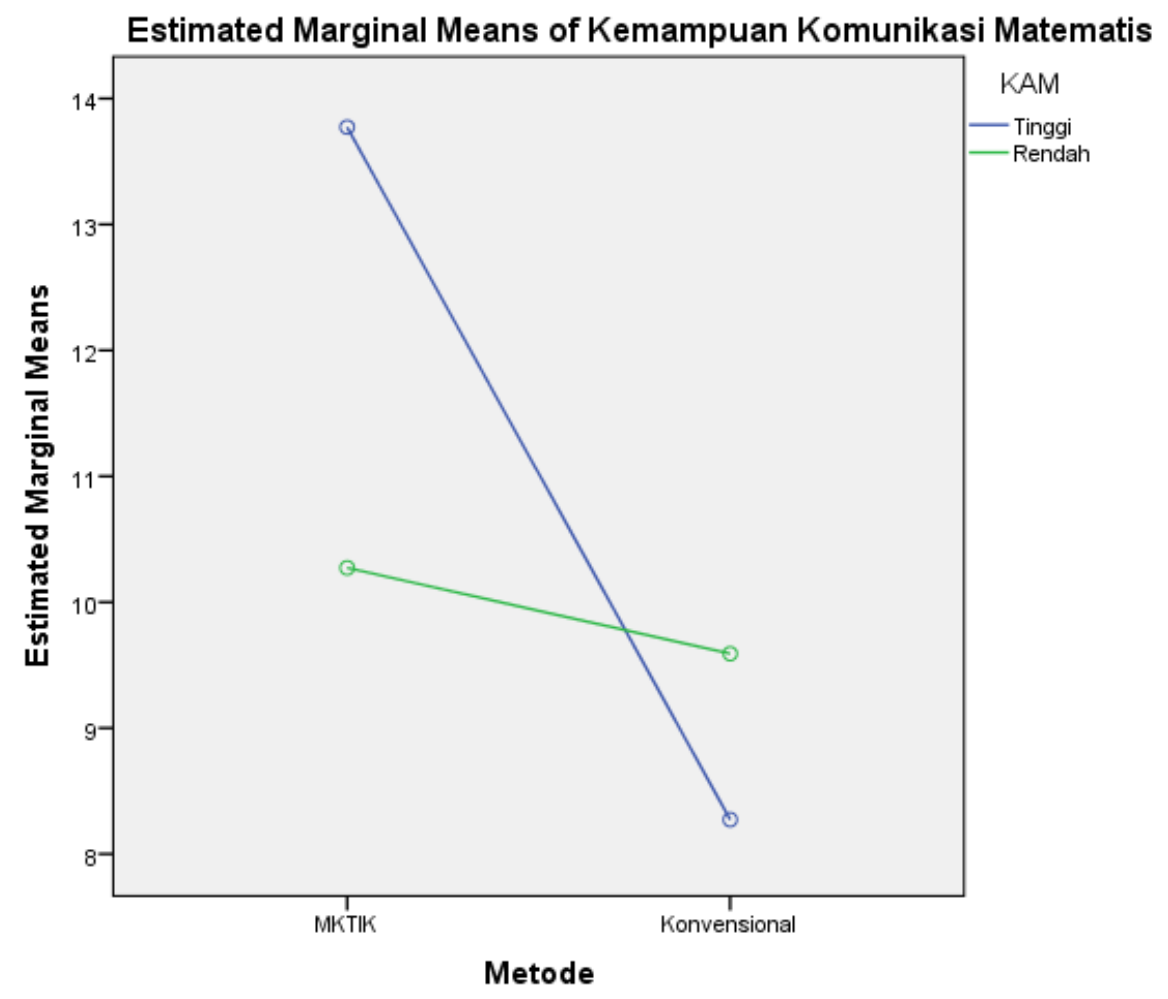

\section{Gambar 1. Grafik Interaksi antara Metode Pembelajaran dan Kemampuan Awal Matematis}

Berdasarkan Gambar tersebut, terlihat bahwa terdapat garis-garis yang tidak saling sejajar atau dengan kata lain, garis-garis tersebut memiliki gradien yang berbeda, sehingga dapat dikatakan bahwa grafik garis-garis tersebut memiliki interaksi, serta kelompok siswa yang belajar melalui MKTIK lebih tinggi dibandingkan dengan siswa yang mendapat pembelajaran konvensional. Jadi, dapat disimpulkan bahwa terdapat interaksi antara metode pembelajaran dan kemampuan awal matematis terhadap kemampuan komunikasi matematis siswa dan dapat disimpulkan juga bahwa MKTIK tepat digunakan pada kelompok siswa yang memiliki kemampuan awal matematis tinggi. 
Pengaruh Penerapan Metode Kooperatif Tipe Investigasi Kelompok Terhadap
Kemampuan Komunikasi Matematis dan Self Confidence Siswa SMP

\section{ERFAN SUFENA, SUYONO, LUKMAN EL HAKIM}

Perbedaan Kemampuan Komunikasi Matematis Siswa dengan Kemampuan Awal Matematis Tinggi yang Belajar melalui MKTIK Dibandingkan dengan Siswa yang Mendapat Pembelajaran Konvensional

Hipotesis penelitian yang ketiga adalah untuk menguji pengaruh siswa yang belajar melalui MKTIK dan pembelajaran konvensional dengan kemampuan awal matematis tinggi terhadap kemampuan komunikasi matematis. Berdasarkan Tabel 1, terdapat interaksi antara metode pembelajaran dan kemampuan awal matematis terhadap kemampuan komunikasi matematis. Berikut disajikan hasil perhitungan dengan menggunakan uji-t.

Tabel 3.

Hasil Uji-t Perbedaan Kemampuan Komunikasi Matematis Siswa dengan Kemampuan Awal Matematis Tinggi yang Belajar melalui MKTIK Dibandingkan dengan Siswa yang Mendapat Pembelajaran Konvensional

Independent Samples Test

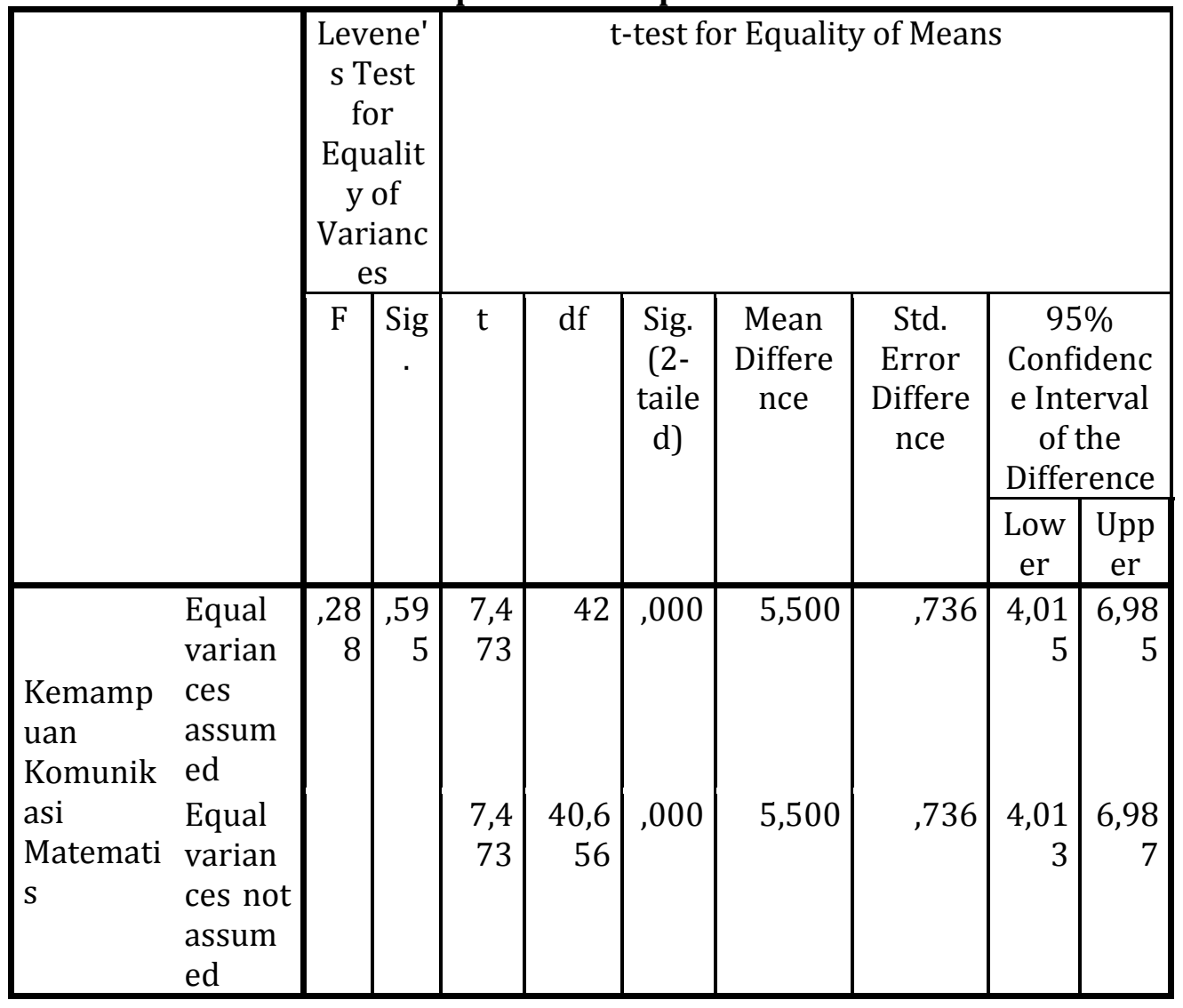

Berdasarkan Tabel tersebut, terlihat bahwa nilai $\mathrm{t}=7,473 \mathrm{dan} \mathrm{df}=42$, pada taraf signifikansi $\alpha=0,05$ dengan menggunakan Microsoft Excel diperoleh nilai $t_{\text {tabel }}$ $=2,018$, sehingga dapat dikatakan bahwa nilai $t>$ nilai $t_{\text {tabel, }}$ yang berarti bahwa hipotesis penelitian $\mathrm{H}_{0}$ ditolak. Jadi, dapat disimpulkan bahwa terdapat perbedaan kemampuan komunikasi matematis siswa yang belajar melalui MKTIK dan pembelajaran konvensional dan juga dapat disimpulkan bahwa kemampuan 
Pengaruh Penerapan Metode Kooperatif Tipe Investigasi Kelompok Terhadap
Kemampuan Komunikasi Matematis dan Self Confidence Siswa SMP

\section{ERFAN SUFENA, SUYONO, LUKMAN EL HAKIM}

komunikasi matematis siswa dengan kemampuan awal matematis tinggi yang belajar melalui MKTIK lebih tinggi dibandingkan dengan siswa yang mendapat pembelajaran konvensional.

Perbedaan Kemampuan Komunikasi Matematis Siswa dengan Kemampuan Awal Matematis Rendah yang Belajar melalui MKTIK Dibandingkan dengan Siswa yang Mendapat Pembelajaran Konvensional

Hipotesis penelitian yang keempat adalah untuk menguji pengaruh siswa yang belajar melalui MKTIK dan pembelajaran konvensional dengan kemampuan awal matematis rendah terhadap kemampuan komunikasi matematis. Berdasarkan Tabel 1, terdapat interaksi antara metode pembelajaran dan kemampuan awal matematis terhadap kemampuan komunikasi matematis. Berikut disajikan hasil perhitungan dengan menggunakan uji-t.

Tabel 4.

Hasil Uji-t Perbedaan Kemampuan Komunikasi Matematis Siswa dengan Kemampuan Awal Matematis Rendah yang Belajar melalui MKTIK Dibandingkan dengan Siswa yang Mendapat Pembelajaran Konvensional

Independent Samples Test

\begin{tabular}{|c|c|c|c|c|c|c|c|c|c|c|}
\hline & \multicolumn{2}{|c|}{$\begin{array}{c}\text { Levene' } \\
\text { s Test } \\
\text { for } \\
\text { Equality } \\
\text { of } \\
\text { Varianc } \\
\text { es } \\
\end{array}$} & \multicolumn{7}{|c|}{ t-test for Equality of Means } \\
\hline & & \multirow[t]{2}{*}{$\mathrm{F}$} & \multirow[t]{2}{*}{ Sig. } & \multirow[t]{2}{*}{$\mathrm{t}$} & \multirow[t]{2}{*}{ df } & \multirow[t]{2}{*}{$\begin{array}{l}\text { Sig. } \\
(2- \\
\text { taile } \\
\text { d) }\end{array}$} & \multirow[t]{2}{*}{$\begin{array}{c}\text { Mean } \\
\text { Differen } \\
\text { ce }\end{array}$} & \multirow[t]{2}{*}{$\begin{array}{c}\text { Std. } \\
\text { Error } \\
\text { Differen } \\
\text { ce }\end{array}$} & \multicolumn{2}{|c|}{$\begin{array}{c}95 \% \\
\text { Confidence } \\
\text { Interval of } \\
\text { the } \\
\text { Difference }\end{array}$} \\
\hline & & & & & & & & & $\begin{array}{c}\text { Low } \\
\text { er }\end{array}$ & $\begin{array}{c}\text { Upp } \\
\text { er }\end{array}$ \\
\hline $\begin{array}{l}\text { Kemampu } \\
\text { an } \\
\text { Komunika } \\
\text { si } \\
\text { Matematis }\end{array}$ & $\begin{array}{l}\text { Equal } \\
\text { varianc } \\
\text { es } \\
\text { assume } \\
d \\
\text { Equal } \\
\text { varianc } \\
\text { es not } \\
\text { assume } \\
d\end{array}$ & $\begin{array}{r}85 \\
1\end{array}$ & $\begin{array}{r}, 36 \\
2\end{array}$ & $\begin{array}{r}92 \\
4\end{array}$ & $\begin{array}{r}41,44 \\
8\end{array}$ & 361 & 682 & ,738 & -808 & $\begin{array}{r}2,17 \\
1\end{array}$ \\
\hline
\end{tabular}

Berdasarkan Tabel dengan SPSS pada lampiran, terlihat bahwa nilai $\mathrm{t}=0,924$ dan $\mathrm{df}=42$, pada taraf signifikansi $\alpha=0,05$ dengan menggunakan Microsoft Excel 
Pengaruh Penerapan Metode Kooperatif Tipe Investigasi Kelompok Terhadap
Kemampuan Komunikasi Matematis dan Self Confidence Siswa SMP

ERFAN SUFENA, SUYONO, LUKMAN EL HAKIM

diperoleh nilai $t_{\text {tabel }}=2,018$, sehingga dapat dikatakan bahwa nilai $t<$ nilai $t_{\text {tabel, }}$, yang berarti bahwa hipotesis penelitian $\mathrm{H}_{0}$ diterima. Jadi, dapat disimpulkan bahwa tidak terdapat perbedaan kemampuan komunikasi matematis siswa dengan kemampuan awal matematis rendah yang belajar melalui MKTIK dan pembelajaran konvensional.

Perbedaan Self Confidence Siswa yang Belajar melalui MKTIK Dibandingkan dengan Siswa yang Mendapat Pembelajaran Konvensional

Setelah dilakukan perhitungan dengan SPSS, diperoleh hasil sebagai berikut:

Tabel 5.

Hasil Uji-t Perbedaan Self Confidence Siswa yang Belajar melalui MKTIK Dibandingkan dengan Siswa yang Mendapat Pembelajaran Konvensional

Independent Samples Test

\begin{tabular}{|c|c|c|c|c|c|c|c|c|c|c|}
\hline & \multicolumn{2}{|c|}{$\begin{array}{c}\text { Levene's } \\
\text { Test for } \\
\text { Equality } \\
\text { of } \\
\text { Variance } \\
\text { s } \\
\end{array}$} & \multicolumn{7}{|c|}{ t-test for Equality of Means } \\
\hline & & \multirow[t]{2}{*}{$F$} & \multirow[t]{2}{*}{$\begin{array}{c}\text { Sig } \\
\text {. }\end{array}$} & \multirow[t]{2}{*}{$\mathrm{t}$} & \multirow[t]{2}{*}{$\mathrm{df}$} & \multirow[t]{2}{*}{$\begin{array}{l}\text { Sig. } \\
(2- \\
\text { taile } \\
\text { d) }\end{array}$} & \multirow[t]{2}{*}{$\begin{array}{c}\text { Mean } \\
\text { Differe } \\
\text { nce }\end{array}$} & \multirow[t]{2}{*}{$\begin{array}{c}\text { Std. } \\
\text { Error } \\
\text { Differe } \\
\text { nce }\end{array}$} & \multicolumn{2}{|c|}{$\begin{array}{c}95 \% \\
\text { Confidenc } \\
\text { e Interval } \\
\text { of the } \\
\text { Difference }\end{array}$} \\
\hline & & & & & & & & & $\begin{array}{c}\text { Low } \\
\text { er }\end{array}$ & $\begin{array}{c}\text { Upp } \\
\text { er }\end{array}$ \\
\hline $\begin{array}{l}\text { Self } \\
\text { Confide }\end{array}$ & $\begin{array}{l}\text { Equal } \\
\text { varian } \\
\text { ces } \\
\text { assum } \\
\text { ed }\end{array}$ & $\begin{array}{r}3,3 \\
59\end{array}$ & $\begin{array}{r}, 06 \\
9\end{array}$ & $\begin{array}{r}2,5 \\
65\end{array}$ & 128 & ,011 & 4,800 & 1,872 & $\begin{array}{r}1,09 \\
7\end{array}$ & $\begin{array}{r}8,50 \\
3\end{array}$ \\
\hline nce & $\begin{array}{l}\text { Equal } \\
\text { varian } \\
\text { ces not } \\
\text { assum } \\
\text { ed }\end{array}$ & & & $\begin{array}{r}2,5 \\
65\end{array}$ & $\begin{array}{r}117,2 \\
84\end{array}$ & 012 & 4,800 & 1,872 & $\begin{array}{r}1,09 \\
3\end{array}$ & $\begin{array}{r}8,50 \\
7\end{array}$ \\
\hline
\end{tabular}

Berdasarkan Tabel dengan SPSS pada lampiran, terlihat bahwa nilai $\mathrm{t}=2,565$ dan $\mathrm{df}=128$, pada taraf signifikansi $\alpha=0,05$ dengan menggunakan Microsoft Excel diperoleh nilai $t_{\text {tabel }}=1,979$, sehingga dapat dikatakan bahwa nilai $t>$ nilai $t_{\text {tabel}}$, yang berarti bahwa hipotesis penelitian $\mathrm{H}_{0}$ ditolak. Jadi, dapat disimpulkan bahwa terdapat perbedaan self confidence antar metode pembelajaran dan dapat disimpulkan juga bahwa self confidence siswa yang belajar melalui MKTIK lebih tinggi dibandingkan dengan siswa yang mendapat pembelajaran konvensional. 


\section{Pengaruh Penerapan Metode Kooperatif Tipe Investigasi Kelompok Terhadap Kemampuan Komunikasi Matematis dan Self Confidence Siswa SMP}

\section{ERFAN SUFENA, SUYONO, LUKMAN EL HAKIM}

Berdasarkan pengujian hipotesis keempat, tidak terdapat perbedaan kemampuan komunikasi matematis siswa dengan kemampuan awal matematis rendah yang belajar melalui MKTIK dibandingkan dengan siswa yang mendapat pembelajaran konvensional. Siswa dengan kemampuan awal matematis rendah kurang memiliki pengetahuan yang cukup untuk dapat mengikuti metode pembelajaran yang diterapkan oleh guru, baik MKTIK maupun pembelajaran konvensional. Sehingga siswa dengan kemampuan awal matematis rendah yang belajar melalui MKTIK tidak berbeda dengan siswa yang mendapat pembelajaran konvensional.

\section{KESIMPULAN}

1. Kemampuan komunikasi matematis siswa yang belajar melalui metode kooperatif tipe investigasi kelompok (untuk selanjutnya disingkat menjadi MKTIK) lebih tinggi dibandingkan dengan siswa yang mendapat pembelajaran konvensional.

2. Terdapat pengaruh interaksi antara metode pembelajaran dan kemampuan awal matematis terhadap kemampuan komunikasi matematis siswa.

3. Kemampuan komunikasi matematis siswa dengan kemampuan awal matematis tinggi yang belajar melalui MKTIK lebih tinggi dibandingkan dengan siswa yang mendapat pembelajaran konvensional.

4. Self confidence siswa yang belajar melalui MKTIK lebih tinggi dibandingkan dengan siswa yang mendapat pembelajaran konvensional.

\section{DAFTAR PUSTAKA}

NCTM. (2000). Principles and Standards for School Mathematics. Reston, Virginia.

Rohaeti, E.E. (2003). "Pembelajaran dengan Metode IMPROVE untuk Meningkatkan Pemahaman dan Kemampuan Komunikasi Matematik Siswa SLTP". Tesis Magister pada PPS UPI Bandung: Tidak Diterbitkan.

Wihatma, U. (2004). "Meningkatkan Kemampuan Komunikasi Matematik Siswa SLTP melalui Cooperative Learning Tipe STAD”. Tesis Magister pada PPS UPI Bandung: Tidak Diterbitkan.

Neill, J. (2005). Wellness \& Outdoor Education. Keynote \& Workshop Presentation to the Victorian Outdoor Education Conference: Essential Learning For Student Well-Being, Geelong Conference Centre, Geelong, Australia.

Lie, A. (2003). 101 Cara Menumbuhkan Rasa Percaya Diri Anak. Jakarta: PT. Elek Media Kumpulan Do Gramedia.

Rohayati, I. (2011). "Program Bimbingan Sebaya untuk Meningkatkan Percaya Diri Siswa". Jurnal UPI, Edisi Khusus: Online. Tersedia di http://jurnal.upi.edu. [diakses 15-02-2017, Rabu, jam 20.55 WIB]

Winayawati, L., Waluya, S.B. \& Junaedi, I. (2012). "Implementasi Model Pembelajaran Kooperatif dengan Strategi Think-Talk-Write Terhadap 
Pengaruh Penerapan Metode Kooperatif Tipe Investigasi Kelompok Terhadap
Kemampuan Komunikasi Matematis dan Self Confidence Siswa SMP

\section{ERFAN SUFENA, SUYONO, LUKMAN EL HAKIM}

Kemampuan Menulis Rangkuman dan Pemahaman Matematis Materi Integral". Unnes Journal of Research Mathematics Education, 1(1): 65-71. [diakses 17-11-2016, Kamis, jam 13.59 WIB].

Solekha, F.N., Noer, S.H. \& Gunowibowo, P. (2013). "Pengaruh Model Pembelajaran Kooperatif Tipe Group Investigation terhadap Kemampuan Komunikasi Matematis Siswa". Jurnal Pendidikan Matematika Unila, Vol 1, No 9. Bandar Lampung: Universitas Lampung.

Edison. (2015). "Peningkatan Kemampuan Pemahaman Matematis dan SelfConfidence Siswa Melalui Pembelajaran Kooperatif Tipe Group Investigation di Sekolah Dasar". Tesis. Bandung: Universitas Pendidikan Indonesia.

Khoerunnisa, E., Hidayah, I. \& Wijayanti, K. (2016). “Keefektifan Pembelajaran Think Talk Write Berbantuan Alat Peraga Mandiri terhadap Komunikasi Matematis dan Percaya Diri Siswa Kelas-VII". Unnes Journal of Mathematics Education, 5, (1). Semarang: Universitas Negeri Semarang. 